\title{
Sociolinguistics in Language Learning and Language Teaching
}

\author{
Xiaoyang Shu \\ Teaching Center, Zhejiang Radio \& TV University, Hangzhou, China \\ Email: sxy327love@126.com
}

How to cite this paper: Shu, X.Y. (2019) Sociolinguistics in Language Learning and Language Teaching. Open Access Library Journal, 6: e5650.

https://doi.org/10.4236/oalib.1105650

Received: July 29, 2019

Accepted: November 19, 2019

Published: November 22, 2019

Copyright $\odot 2019$ by author(s) and Open Access Library Inc.

This work is licensed under the Creative Commons Attribution International License (CC BY 4.0).

http://creativecommons.org/licenses/by/4.0/

\section{(c) (i) Open Access}

\begin{abstract}
The past decades have seen many linguists, psychologists, and educationalists involved in the area of language learning and language teaching, while this paper will deal with it from sociolinguistic point of view. It's obvious that different branches of sociolinguistics have had considerable impact on second language teaching. Since the late 1960s sociolinguistics have mainly focused their attention on how language is used appropriately in varying contexts. Therefore this paper will explore communicative approach that is founded on the basis of communicative competence. Finally this paper argues that the most important role of sociolinguistics in language teaching is to provide the learners with the appropriate rules of speaking and writing and raise their sociolinguistics awareness.
\end{abstract}

\section{Subject Areas \\ Education, Linguistics}

\section{Keywords}

Language Learning and Language Teaching, Sociolinguistics, Communicative Approach, Communicative Competence, Sociolinguistics Awareness

\section{Introduction}

Since the late 1960, sociolinguists have paid their attention to naturally occurring language use. This made second language specialists look to sociolinguistic research for developing teaching methodologies and enlarging the area of objectives of language education [1] [2].

Language education involves not only the elaboration of a grammatical system, but also the ability to use language as an instrument for learning and the ability to use language appropriately in varying contexts. It reflects function and 
communicative uses of language [3] [4]. In this paper, the writer argues that communicative approach founded on the basis of communicative competence is not a panacea and the role of sociolinguistics in language teaching is to provide the learners' sociolinguistics awareness.

\section{An Exploration of Communicative Competence}

The term communicative competence is first put forward by Hymes (1972), an American sociolinguist. He put forward this term partly to contrast with Chomskey's linguistic competence. In Chomskey's point of view, linguistic competence can be seen as an innate biological function of mind that allows individuals to produce the indefinitely large set of sentences that constitutes their language. But a growing number of researchers regard it as an idealized notion, therefore, it is inadequate. Then in 1972, Hymes put forward the concept of communicative competence. In his view, the concept of competence should include language use as well as sentence creation and a speaker needs to know how to be communicatively competent in a speech community.

Linguistic competence is highly abstract, while communicative competence focuses on practicality. Therefore, they are on different levels. Hymes's theory of communicative competence deeply affects the domain of language teaching and challenges traditional teaching approaches. In China, communicative approach was developed in 1960.

\section{Communicative Approach}

1) In communicative approach, the main features of it are as follows:

a) Communicative approach argues that language is an instrument for communication and learning language should include language use as well as language forms. Therefore, to make a distinction between usage and use is needed. For example, in the street, a stranger asks you the way:

$\mathrm{T}$ : Could you tell me the way to cinema, please?

You: It's fine today.

Obviously, there is no grammatical mistake in your answer, but the purpose of communication fails. So, grammatical competence doesn't stand for communicative competence, while communicative competence should include grammatical competence. However, in China, there is a misconception that communicative competence only refers to the ability to speak elegant English.

b) Communicative approach holds that we should create the real communicative environment in order to achieve real communication. For example, the teacher, pointing to Student B, asks Student A:
$\mathrm{T}$ : What's his name?
A: His name is Zhang Hong.
T: Where's he from?
A: He is from Zhejiang.
$\mathrm{T}$ : Is he studying English?
A: Yes, he is.

Communicative approach views this dialogue as "false communication" because the student and teacher have known these information. 
c) Communicative approach insists that it is necessary to use authentic materials as teaching materials. For example, telephone dialogue should be recorded on the cassette and recorded materials can use dialect instead of RP. The introduction of some place can be presented to the students through movie in order to let them "reach" the real one.

It is no doubt that all of these features correspond to communicative competence. Communicative approach emphasizes how language is used in real social settings to perform communication function and how language is used in varying contexts. For example, the students in China would like to ask the foreigners such questions: What's your name? How old are you? Where do you come from? Do you like Beijing? It reflects they have linguistic competence but no social competence. And it is partly caused by our Junior English textbooks full of such kind of sentences, so the students only know to use this way for communication. While in English-speaking countries, linguistic competence and social competence should be combined to learn. For example, the family invited many friends to have a dinner. When they were preparing for dinner, the host had a call and the guests didn't eat, waiting for him politely. At this moment, the host's four-year-old child said to his mother, "I'm hungry, Mum". The hostess said in a low voice, "Don't be rude!" So the child learned that it was impolite to say so in front of the guests. From this example, it is found that why communicative approach prefers real communicative settings. At the same time, it reflects the role of social interaction in language learning. The hostess as a parent can have a great influence on her child's learning, which is emphasized by Soviet Activity Theory. This theory provides insight into the social factors in children's language development. In this theory, it is assumed that individuals can acquire knowledge and skills by participating in activities with more experienced members of culture.

\section{2) Communicative competence defined by Canale and Swain (1980)}

However, with the existing policy of English Proficiency Test in China, students have to focus their attention on language form and accuracy. Therefore we should have a correct knowledge about communicative competence. In 1980, Canale and Swain had a perfectly summarized communicative competence, holding that there are four areas of knowledge and skills: grammatical competence, discourse competence, strategic competence, and sociolinguistic competence.

a) Grammatical competence covers the mastery of phonological rules, lexical items, morphosyntactic rules and rules of sentence formation. It refers to what Chomskey calls linguistic competence.

b) Discourse competence involves mastery of how to combine grammatical forms and meanings to achieve a unified or written text in different genres such as narrative, argumentative essay, scientific report or business letter.

c) Strategic competence involves the mastery of verbal and nonverbal strategies to compensate for breakdowns and to enhance the effectiveness of communication. 
d) Sociolinguistic competence refers to an understanding of the social context in which communication takes place, including role relationships, the shared information of the individual message elements in terms of their interconnectedness and of how meaning is represented in relation to the entire discourse or text.

Canale and Swain's view of communicative competence somewhat makes up for the defect of the communicative approach because it not only stresses language skills, especially speaking skills, but also emphasizes grammar and vocabulary teaching. Though their view of communicative competence seems satisfactory, teachers feel that they will sway between traditional approaches and communicative approach because they have no enough time to deal with grammar and vocabulary. Now, many students are good at speaking and listening, but poor in grammar and translation. And in China, because of cultural background, from kindergartens and primary schools, students are accustomed to memory, imitation and repetitive practice, and they find it difficult to adjust themselves to communicative approach. For example, there is a conversation between a student and the teacher:

S: I have really enjoyed these classes, but what did I learn?

T: You spoke very much. $\quad$ S: But what did I learn?

T: You learned to speak!

S: But what can I take home? I have nothing in my book, no notes, no grammar.

T: But you can speak English now.

S: Will that help me in the exam?

Therefore, the writer argues that adopting communicative approach plus Chinese ways of learning is more useful to Chinese students. And the most important of sociolinguistics in language teaching is to provide the learners with the appropriate rules of speaking and writing and raise their sociolinguistics awareness, that's to say, the awareness of the socio-cultural differences across languages.

\section{Conclusion}

This paper insists that sociolinguistics have had a great and direct impact on language teaching. Simultaneously, this paper argues that communicative approach founded on the basis of communicative competence should be adopted plus Chinese ways of learning. And communicative competence defined by Canale and Swain seems highly perfect, but language teaching should serve the development of these four components of communicative competence and raise the learners' sociolinguistics awareness.

\section{Acknowledgements}

My thanks to the anonymous reviewers for reading and commenting on the early drafts of this article. 


\section{Supported}

The project is supported by Zhejiang Social Science Project (Grant No. 2018SCG 259), The Project of Open University of China in 2008 (Grant No. G18A1630Y), Social Science Project of Hangzhou in 2017 (Grant No. M17JC021), Foundation of Zhejiang Educational Committee (Y201839612).

\section{Conflicts of Interest}

The author declares no conflicts of interest regarding the publication of this paper.

\section{References}

[1] Coulmas, F. (1997) The Handbook of Sociolinguistics. Blackwell Publishers Ltd, Hoboken.

[2] Scarcella, R.C., Andersen, E.S. and Krashen, S.D. (1990) Developing Communicative Competence in a Second Language. Newbury House Publishers, New York.

[3] Hu, W.Z. (1989) Teaching and Learning of English. Foreign Language Teaching and Research Press, Beijing.

[4] Hu, W.Z. and Gao, Y.H. (1997). English Teaching and Culture. Hunan Education Publishing House, Changsha. 